\title{
PRODUCTIVE COMPLEX OF DEFENSE AND SECURITY IN BRAZIL: DIMENSIONAL, SECTORAL AND TECHNOLOGICAL IMPACTS
}

\author{
Paulo César Morceiro * \\ Milene Simone Tessarin \\ JoAquim José Martins Guilhoto ${ }^{\dagger}$
}

\begin{abstract}
Resumo
Mensurou-se de forma inédita o complexo de defesa e segurança brasileiro. Ele correspondeu a 3,7\% do PIB do Brasil em 2014. Também verificou-se que os projetos de investimento das Forças Armadas apresentam impactos socioeconômicos elevados e grande potencial tecnológico ao demandar produtos e serviços de alta tecnologia. Foram levantadas informações não publicadas junto a diversos órgão públicos (Ministérios, Secretarias Estaduais, Portal da Transparência). Com isto, estimamos os setores de defesa e segurança na matriz de insumo-produto brasileira e identificamos o perfil setorial dos projetos de investimentos de defesa. Esta metodologia inovadora pode ser aplicada para avaliar outras políticas públicas.
\end{abstract}

Palavras-chave: complexo produtivo de defesa e segurança; projetos de investimento; transbordamentos tecnológicos; análise de insumo-produto; Forças Armadas.

\begin{abstract}
In a novel way, we have measured the Brazilian defense and security complex. It corresponded to $3.7 \%$ of the Brazilian GDP in 2014. We have also estimated that the investment projects of Armed Forces have high socioeconomic impacts and great technological potential by demanding high-tech products and services. Unpublished information was collected from several public agencies (Ministries, Public Security, and Government Transparency Portal). With this, we estimate the security and defense sector in Brazilian input-output matrix and identify the sectoral profile of the defense investment projects. This innovative methodology can be applied to evaluate other public policies.
\end{abstract}

Keywords: productive complex of defense and security; projects of investment; technological spillovers; input-output analysis; Armed Forces.

JEL classification: $\mathrm{H} 56$; O22; O14; $\mathrm{C} 67$.

DOI: http://dx.doi.org/10.11606/1980-5330/ea 132559

\footnotetext{
${ }^{*} \mathrm{PhD}$ at University of São Paulo (FEA-USP). Postdoctoral researcher at South African Research Chair Initiative in Industrial Development (SARChI) from the University of Johannesburg.

${ }^{\dagger}$ OECD and University of São Paulo. The content of this publication expresses the views of this author and does not necessarily represent the views of the OECD or its member countries.
} 


\section{Introduction}

The industry ${ }^{1}$ of defense and security ${ }^{2}$ sector engages in a series of production and service activities that, beyond their contribution to national security and sovereignty, play an important role in terms of technological development, labor qualification, and social and economic impacts. According to Sandler \& Hartley (1995), the establishment of productive sectors related to the military promotes the welfare of the host country, which reflects in the generation of technological spinoffs to other related industries, and military research and development (R\&D) spillover to civil sectors Guillou et al. (2009). The latter issue supports the creation of a common technological base involving diffe-rent institutions, techniques, and administrative arrangements (Dunne (1995), Kulve \& Smith (2003)) for the technological progress of the country.

Since the Second World War, several countries, including the United States invested, both directly and indirectly, voluminous amounts in $\mathrm{R} \& \mathrm{D}$ and human resources in the defense sector (Mowery \& Rosenberg (1999); Hartley (2008); Mowery (2012)). More than half of the US government investments in R\&D during the last three decades related to defense (Mowery (2012); OECD (2016)); in 2013, the US investment in R\&D was $0.76 \%$ of its GDP, out of which $52.7 \%$ went towards defense, including military, nuclear, and space industries (OECD (2016)). Allied to public R\&D, the government demand of goods and services for military purposes, particularly in the initial stages of projects, plays an important role in the creation of several critical technologies (general purpose technologies), such as integrated circuits and computers (Freeman (2013), ch. 10; Mowery \& Rosenberg (1999), ch. 5; Breakthrough-Institute (2010), pp. 16-21); jet aircraft engines (BreakthroughInstitute (2010), pp. 13-14); civilian nuclear energy, lasers, and biotechnology (Block (2008), pp. 174-175); internet and GPS (Breakthrough-Institute (2010), pp. 22-24; Mazzucato (2015), ch. 5); software (Mowery \& Rosenberg (1999), ch. 5); and iPhone/iPad/iPod's main technologies (BreakthroughInstitute (2010), pp. 4-5; Mazzucato (2015), ch. 5), among others. Thus, public policies play an important role in stimulating innovations that become vehicles of structural change in the economy (Guillou et al. (2009); Reati (2014)).

Therefore, the State through its defense budget helped reduce the risk and technological uncertainties, reduce the price and improve the reliability and functionality of new technologies Mowery (2012).

Furthermore, the economies of scale and price reduction through early versions of the new Armed Forces technology resulted in the civil markets becoming more price sensitive to these technologies (Mowery (2012)). Thus, several significant technologies developed for the defense sector ended up spilling over to the civil sector, thus benefitting all people (Mowery \& Rosenberg (1999); Kulve \& Smith (2003); Molas-Gallart (1997); Mowery (2012)). Recently, China's civil sector has been showing substantial technological progress

\footnotetext{
${ }^{1}$ The authors thank Denise Imori, research assistants Gabriel Single Toledo and Caio de Souza Castro and the NEREUS members by technical support and comments. We also thank the anonymous referees and the editors of Economia Aplicada, who helped to improve the paper. We thank the Brazilian Association of the Material Industries of Defense and Security (ABIMDE) and FIPE for their financial and technical support.

${ }^{2}$ While defense activities are classified under code 8422 of ISIC 4 (International Standard Industrial Classification of All Economic Activities, Rev.4), public safety activities fall under code 8423 and private security comes under code 80 .
} 
in dual-use technologies with decisive support from the government and military budget in the following fields: electronics, computing and information and communications technology (ICT), computer-aided manufacturing (3D printing), space technology and satellites, aeronautics, and shipbuilding (Trebat \& Medeiros (2014)).

Despite its modest setting compared to world leaders, the Brazilian defense sector has permanent R\&D teams, especially for the Navy and Air Force; furthermore, educational institutions connected to the Armed Forces have always excelled in quality, ranging from high school to postgraduation. Brazil is a relevant actor in the defense sector. In 2015, it held the eleventh place in the world in military expenses. However, regarding GDP percentage, the country's military expenditure represented only $60 \%$ of the world average. In contrast, the US military expenses were 2.4 times higher in GDP percentage (Perto-Freeman et al, 2016). ${ }^{3}$ Brazil also possesses an expressive safety sector. Like other developed democracies, Brazil witnessed the growth of safety services since the 1960s (Shearing, 1992) and restructuring of the policing function, which was fulfilled by non-governmental groups along with public agencies (Bayley \& Shearing, 2001).

The growth of safety services is due to the change in social structure of the verified countries, especially in big urban centres (Aslam, 2007), and the formation of semi-public areas (such as residential condos, commercial complexes, and big shopping districts) (Caldeira, 2000; Minhoto, 2002), and important changes in awareness of the role of Social Security, allowing for the coexistence of private and public security services (Shearing, 1992; Bayley \& Shearing, 2001).

Public security includes the military police of the 27 federation units (FUs) of Brazil and the Federal Police that has a strong contingency due to the country's wide territorial dimension and the need to ensure safety in urban areas, for example, in the highly populous cities of São Paulo (above 10 million inhabitants), Rio de Janeiro, Salvador, Brasília, and Fortaleza (around 2.5 to 6.5 million inhabitants). Private security has grown and supports the various sectors in society (the public sector and the financial, industrial, and service sectors).

Despite its smouldering importance, only a few papers have examined the Brazilian defense and security sector. The country still needs to gain basic information on and evaluate its public policies aimed at this sector.

Therefore, the main objective of this study is to quantitatively measure the value chain and socioeconomic importance of the defense and security sector in Brazil. For that, we need to perform the unprecedented task of measuring the GDP of the country's defense and security complex (public and private) from 2009 to 2014. This will also evaluate the impacts on the economic and social variables of the Brazilian Army, Navy, and Air Force's 23 priority investment projects, defined as the Plan on Articulation and Defense Equipment (PADE) ${ }^{4}$ of the Armed Forces of Brazil, which holds a programmed budget of US\$ 193.8 billion for the period of 2012-2031.

PADE is the Brazilian government's main purchase programme for its defense sector to equip the Armed Forces and decrease the gap in technologies

\footnotetext{
${ }^{3}$ In absolute values, the US military budget was 24 times the Brazilian budget in 2015, representing $35.6 \%$ of the world total (Perlo-Freeman et al., 2016, pp. 2).

${ }^{4}$ Plano de Articulação e Equipamento de Defesa (PAED), in Portuguese.
} 
considered strategic to national sovereignty. The government's perennial orders related to PADE are vital to the survival and technological development of the defense industry and, to a lesser extent, security. Many companies benefitted from PADE, like EMBRAER (the world's third-largest plane manufacturer), whose production targeted both the military and civil sectors. Certainly, the technological challenges that EMBRAER faced in developing the military cargo plane KC-390 of EMBRAER had a direct impact on its civil commercial aviation production.

In order to measure the GDP of the defense and security complex, we need to estimate the input-output system of the Brazilian economy, which would properly explain the economic sectors linked to the defense and security sector. The estimation of the aforementioned input-output system necessarily involves the collection, compilation, and treatment of information available on various databases, because defense and security activities are not disaggregated in the input-output matrices or disclosed in resource tables and uses of the Brazilian Institute of Geography and Statistics (IBGE).

Thus, in the section following these introduction, we present the database used to delimit the defense and security activities; this is based on purchases made by the Brazilian government (at the federal, state, and municipal levels), representing more than $90 \%$ of the sales in these activities. Thus, the defense and security sector is delimited by the claimant sector (based on the purpose of the product). This work covers the investment data and other current expenditures (maintenance and operation costs) related to the Brazilian defense and security activities. In the succeeding section, we present in detail the input-output matrix methodology used in this paper. The results of applying this methodology are presented in the following subsections.

Section 4.1 analyses the GDP of the defense and security complex (public and private) for each year from 2009 to 2014. The results are presented in Section 4.2 by the defense and security complex component (defense and security activities, industries, supplies, services, and distribution), detailing the private security, state public security, federal public security, and national defense activities.

Complementing the analyses of the socio-economic importance of the defense and security industry in Brazil, Section 4.3 presents important indicators such as the multipliers of output and employment (direct and indirect), as well as scale impacts on the Brazilian economy of 23 PADE investment projects. The final subsection shows the productive sectors impacted by PADE, especially the high and medium-high technology industries and knowledge-intensive services. The final section presents our concluding comments.

\section{Data Treatment}

In this study, the defense and security sector is delimited on the purchases made by the Brazilian government (at the federal, state, and municipal levels), representing more than $90 \%$ of the sales in this sector. Thus, the defense and security sector is delimited by the demanding sector (based on the product's final purpose). This procedure is a distinction of this study, and it isolates the goods with the purpose of defense and security from the goods for civil use. This is important because many products, for example, radars, planes, ships, 
vehicles, and communication equipment have dual use, making it practically difficult to identify the goods and services used for Defense and security in the industrial classification based on economic activity (Molas-Gallart, 1997; Rogerson, 1994; Dunne, 1995). This study covers the fixed investment data and other current expenditures (expenditures of maintenance and operation) related to activities of the Brazilian defense and security for measuring the GDP of this complex.

This section is divided into two subsections. The first subsection presents the data tabulated for decomposition on the input-output matrix of the defense, state public security, federal public security, and private security sectors. The second subsection presents the methodology developed to map the average profile (or composition) of each of PADE's 23 investment projects.

\subsection{Disaggregation of the Defense and Security Sectors in Input-Output Matrix}

The difficulty in defining companies, products, and services specifically for defense and security is a characteristic that differentiates the defense sector and security from other sectors of the economy (Rogerson (1994); Dunne (1995)), and is a major obstacle to the formulation of public policies and their monitoring.

Generally, producer companies interleave their production between military goods and civilian goods, because the production of military items is not perennial, but by projects (on demand). In 2013, 100 of the largest corporate revenues from the sale of military goods and services accounted for just $32 \%$ of the total turnover of these companies; that is, $68 \%$ of the revenue was obtained from the sale of goods for civilian use (SIPRI $(2011))^{5}$. In Brazil, Brick (2014) identified the companies in the defense and security sector that have a higher percentage of sales linked to non-military goods and services, and by contrast, have a lower share in relation to goods for military use.

In addition, the composition of the Brazilian defense and security industry is not fully known (Araújo et al. (2010); Schmidt \& Assis (2013)), because in general, large companies are identified, but the small and medium enterprises, or those that provide components or serve other companies in the military area or the Armed Forces directly, are not fully known.

Another relevant issue differentiating the dynamics of this productive sector from others is its monopsony structure, by which nation states are practically the only claimants of the products destined for defense and security or having a military destination (Smith (1990); Rogerson (1994); Dunne (1995)). This power is exercised on demand both in the domestic and foreign markets, where the state defines the assets that can be marketed (Markusen (1986); Schmidt \& Assis (2013)). With regard to external trade, defense and security products form part of the group not governed by the World Trade Organization (WTO) for national sovereignty reasons (Dunne (1995); Correa Filho et al. (2013)). Thus, importing a product designed for defense and security will be authorized only if the Armed Forces of the product's country of origin do it; otherwise, it may not be marketed. Therefore, the production dynamics of this complex is determined not by supply, but by demand and political and strategic considerations (Amarante (2012); Correa Filho et al. (2013)).

\footnotetext{
${ }^{5}$ The list of the 100 largest business revenues from the sales of military products and services does not include Chinese companies SIPRI (2011)
} 
These characteristics led us to determine the production of the defense and security sector differently from the traditional method, which involved calculating the production from the perspective of the company. However, we determine the production based on the value of public purchases of products and defense and security services from the consumers' perspective ${ }^{6}$.

Thus, in this study, we delimit the defense and security activities in Brazil by considering the purchases of goods and services made for defense and security purposes by the Federal Government, the 27 FUs, the State Government, and private security companies. Thus, the defense and security activities are divided into the public sphere (national defense, federal public security, and state public security) and private sphere (private security). For the public sphere, we accessed purchases made by the federal and state agencies for investment and other current expenses, the first used as proxy for Gross Fixed Capital Formation (GFCF), and the latter as proxy for intermediate consumption.

The set of goods and services classified as investments refers to the costs of fixed investments in building, such as expenses for the planning and execution of works and installations, and costs of equipment and supplies for permanent assets such as aircraft and ships. With these, we could disaggregate the existing investment vector in the input-output matrix between investments made for defense and security activities and investments made for other productive activities. Finally, the goods and services classified as other current expenses refer to the expenditure for purchasing consumable goods, payment services, daily payments, tickets, and aid (food and transportation, for example), among other types of expenditures that will compose the intermediate consumption vectors related to defense and security in the inputoutput matrix (hereafter, matrix).

As regarding the private sphere, we find the production and investment are available for this service activity, requiring some considerations for fit in use matrix.

In the following subsection, we present the main sources of information of the activities related to national defense and federal public security. The succeeding subsections provide the sources of information related to the state public security sector and private security sector.

\section{National Defense and Federal Public Security Sector: Description of Information}

In Brazil, the Ministry of Defense is responsible for the maintenance and operation of the National Armed Forces, while the Ministry of Justice is responsible for the procurement of goods and services for federal public security, which includes organs of the Department of Federal Highway Police, Federal Police Department, National Penitentiary Fund, Fund for Devices and O-

\footnotetext{
${ }^{6}$ It is noteworthy that from the perspective of supply (or production enterprises by the main activity), we have only two specific codes related to defense products, CNAE 2.0 \#25.5, corresponding to the manufacture of heavy military equipment, firearms, and ammunition, and CNAE $2.0 \# 30.5$, representing the manufacture of military fighting vehicles. For confidentiality, the IBGE does not disclose information on the latter CNAE. However, several products used for defense purposes, such as airplanes, ships, and communications equipment (radars, for example), are classified in sectors of activity along with civilian use products, and hence it is not possible to distinguish these goods for military purposes. The size of the defense and security complex on the demand side, as proposed by this study, seeks to remedy these difficulties.
} 
perating Activities of the Federal Police, National Public Security Fund, and National Anti-Drug Fund.

Through the Access to Information Act (\# 12,527 of 2011), we could find the information of purchases made by the agencies of these two ministries for the period of 2009-2014, as provided by SIAFI (Integrated System of Financial Administration of the Federal Government, agency of the National Treasury Secretariat). The data collected showedhuge disaggregation under an eightdigit classification used by the Brazilian government, called nature's expense. Purchases made by the Ministry of Defense were broken down into 393 goods and services classified as investments and 657 goods and services classified as other current expenses; and purchases made by the Ministry of Justice were broken down into 45 products and services classified as investments and 222 products and services classified as other current expenses.

To this information, we added the values of each item respectively in Reais $(\mathrm{R} \$)$ on a classification compatible with the Brazilian input-output matrix ${ }^{7}$, which requires the division of 186 products of agriculture, industry, and services.

For compatibility between the SIAFI products and the 186 products of the input-output matrix, a specific translator called 'products and services classified from SIAFI x 186 products input-output matrix' was developed. This translator is based on (i) the description of the SIAFI products ${ }^{8}$, (ii) the products listed in the PRODLIST - industry IBGE with an eight-digit breakdown (product level), and (iii) auxiliary tables of correspondence developed by IBGE providing information on the products and their correspondence with the National Classification of Economic Activities (CNAE) ${ }^{9}$.

When the products were compatible, we obtained the intermediate consumption vectors of the activities related to the defense sector and the federal public security sector. We then subtracted these vectors from the existing vector in the input-output matrix called 'Public Administration and Social Security', which consolidated the purchases of the Brazilian public sector. The base year was taken as $2009^{10}$, and later this was adjusted according to the New System of National Accounts (released by IBGE in 2015), which incorporated the latest information on the economic structure of Brazil. By using this procedure and the investment information and other current expenditures for the period of 2009-2014, we could obtain the annual information for the year 2014.

In order to obtain the complete information required to draw up the inputoutput system, we also sought information on the number of jobs, amount of compensation, the value added, and output of the defense and federal public security sectors. For the defense sector, we obtained both the number of employees and amount of compensation from the RAIS/MTE (Annual Relation of Social Information/Ministry of Labor and Social Security) and

\footnotetext{
${ }^{7}$ This matrix consists of 133 activity sectors and 186 products and was developed by Prof. Dr. Joaquim José Martins Guilhoto in the Nereus's scope (USP Regional and Urban Economics Lab).

${ }^{8}$ We used documents drawn by SIAFI on the nature of spending by sub-item, which indicated the products included in each type of nature expenses.

${ }^{9}$ The Brazilian classification is similar to the International Standard Industrial Classification of All Economic Activities. Classificação Nacional de Atividades Econômicas (CNAE), in Portuguese.

${ }^{10}$ At the commencement of this work, information on the IBGE's National Accounts annual system was available only up to 2009 as base for input-output matrices.
} 
CAGED/MTE (Record of Employed and Unemployed/Ministry of Labor and Social Security), using as criteria \#84.22 - defense (CNAE version 2.0). For the federal public security sector, we used the information on jobs and wages obtained from the Ministry of Justice. In this case, we considered the number of persons employed in organizations related to federal public security, that is, the Federal Police and the Federal Highway Police.

Finally, we obtained the value added data by adding the compensation (wages and social contributions) and the gross operating surplus, the latter obtained through estimation. We then obtained the value of output by adding the intermediate consumption and value added.

In regards to the defense sector, we need to emphasize that we considered the salary information and social contribution of the active personnel only, so for the matrix data, we excluded the expenses of inactive personnel (retirees and pensioners) during 2009-2014, which accounted for about $45 \%$ of the total budget of the Ministry of Defense.

\section{State Public Security Sector: Description of Information}

For data on public security activities, that is, the competence of the states of the federation, we requested information from the respective state finance departments (SEFAZ), or the responsible agency. Note that the lack of standardization of information among states hampered our data and treatment of data.

For the period of 2009-2014, we managed to obtain quality information and disaggregated the information in terms of product and service for 7 of the 26 Brazilian states (and the Federal District), namely, São Paulo, Minas Gerais, Rio de Janeiro, Rio Grande do Sul, Paraná, Goiás, and Espírito Santo, which together accounted for $56.2 \%$ of the population in 2014 . For the other 19 states of the federation, representing $43.8 \%$ of the population, the expenses related to investments and other current expenditures were estimated considering the population of the states and the value indicated by the Ministry of Justice and the per capita expenditure attributed to the FUs' public security function. Thus, we obtained the whole volume of purchases related to state public security.

After finding the data source of each of the seven states, we checked the items classified as investments and other current expenses. Since there is no standardization in the disclosure of the data (some are more and some less disaggregated with different denominations), we had to create specific translators for each state to reconcile the data with the 186 products and services of the Brazilian input-output matrix.

After completing the work of interpreting the codes and estimating the information of the other states, we added the values of all states to obtain a single vector of intermediate consumption and investment. The vector of intermediate consumption was then subtracted from the existing column ' $\mathrm{Pu}$ blic Administration and Social Security' in the input-output matrix.

Thus, the original activity sector, Public Administration and Social Security, was disaggregated into four sectors, (i) Defense (ii) Federal Public Security, (iii) State Public Security, and (iv) other Public Administration and Social Security.

We obtained the information of personnel in the state public security sector included in the input-output matrix from annual reports of the Ministry 
of Justice, which has effective control of every FU public security function, including the military police, civil police, fire department, municipal civil guard, and traffic agents.

We obtained the information of compensation from the RAIS/MTE in consultation with codes 84.24 (Public Order and Security) and 84.25 (Civil Defense) of CNAE 2.0, less the value of compensation related to federal public security obtained from the Ministry of Justice. ${ }^{11}$

Finally, as done previously, we calculated the value added and the value of output using the definitions of these variables, that is, the value added to the sum of earnings (wages and social contributions) and gross operating surplus; output is the sum of intermediate consumption and the added value.

\section{Private Security Sector: Description of Information}

We obtained the information of private security activity from a search of the Annual Services Survey of IBGE (PAS/IBGE), which presents some data (on value of output, added value, intermediate consumption, and investments) related to the service sectors of the Brazilian economy, including 'research services, surveillance, security and transport value' (code 80 of CNAE 2.0), which we use in our discussions.

We collected data for the years 2009-2012, the last period for which PAS refers to; for 2013 and 2014, our estimates are based on the number of jobs available in RAIS and CAGED/MTE relating to code 80 of CNAE 2.0.

For activities related to the private security sector, the value of intermediate consumption in PAS/IBGE is given in total; that is, it is not disaggregated into the products and services purchased. In order to disaggregate this, we use the structure of the New System of National Accounts of IBGE, taking as support for new use tables based on the year 2010, which shows the private security sector individually. Thus, we could calculate the intermediate consumption sector disaggregated into products of the input-output matrix.

Following this, we subtracted the intermediate value of the consumption column of the sector 'business services' from the values corresponding to private security activity. Thus, the original business services sector was decomposed into two, (i) private security and (ii) other business services.

On disintegrating the activities related to defense and security, we obtained a disaggregated input-output matrix of 190 products in 137 sectors, of which 133 are original while the other four are defense and security sectors created by this methodology.

The PAS/IBGE also provides the investment information of private security activity, but the total investment is divided into five major groups, namely, (i) machinery, equipment and facilities, including data processing equipment, (ii) means of transportation, (iii) buildings, (iv) land, and (v) others (furniture, appliances, etc.). For more disaggregation and consistency, we used these investments as a weight of the set of investments of the state public security sector, thus obtaining greater distribution in terms of number of products purchased by the private security sector. Following this, we subtracted the GFCF column of the Brazilian economy from the investment column of the private security sector, thus forming the column 'GFCF private security'.

${ }^{11}$ The two cited CNAEs include state and Federal Police. 
Thus, the GFCF column of the original Brazilian economy has been disaggregated into five pillars: (i) GFCF of Defense, (ii) GFCF of Federal Public Security, (iii) GFCF of State Public Security, (iv) GFCF of Private Security, and (v) other GFCFs of the Brazilian economy.

The PAS/IBGE also provides information on the number of employees, salaries, and other compensations of the private security sector for 2009-2012. For the values of the years 2013 and 2014, we use the RAIS and CAGED, referring to the employed persons and balance of jobs created in CNAE 2.0 \#80, that is, surveillance activities, security, and investigation. We also obtain the added value and output from PAS/IBGE.

\subsection{Profile of the Investment Projects of PADE}

In 2012, the Brazilian Ministry of Defense published the White Book of National Defense (LBDN (2012)), providing the guidelines and goals of the Armed Forces in the context of the national defense strategy - END (2008). The WBND (LBDN (2012), ch. 5) describes PADE of the Armed Forces of Brazil; this brings together the strategic projects of the Army, Navy, and Air Force and the programmed expenditure of each project for the period of 2012-2031. The budget for all the projects in this period will be US\$ 193.8 billion at 2014 prices (see Table 1).

The 23 investment projects of PADE involve various actions, such as harmonization projects of the Armed Forces, the recovery of operational capability, education and R\&D activities, transfer of technology, and acquisition of defense equipment (as described in the LBDN (2012), pp. 202-206). For instance, the Navy project 'M3 - Construction of the Centre of Naval Power' foresees the construction of a dockyard for submarines, the construction of submarines (four conventional ones and one with nuclear propulsion), the development of national capacity to design and build ships, and the creation of a battalion of marines.

Among the Army projects, the 'E3 - New Family of Armoured Vehicles (Guarani)' foresees the development and production of bulletproof and amphibious vehicles in the country, adoption of the most recent technologies, procurement of simulation systems, nationalization of ammunition, integrated logistical support, and training of human resources.

In regards to the Air Force, project 'A5 - Scientific-Technological Training Air Force' aims at national technological emancipation for manufacturing aerospace defenses, the development of data communication technologies and unmanned aircrafts, and the development and acquisition of fighter aircrafts, helicopters, flight simulators, transport and fuel planes, and search and rescue planes ${ }^{12}$.

As shown previously, priority projects cover diverse productive sectors (especially of high technology), confirming the relevance of PADE projects for the productive and technological development of the country, as pointed by Amarante (2012).

To obtain the industry average profile for each of the 23 investment projects shown in Table 1, that is, to obtain the expenditure for each of the sectors of activity of the Brazilian input-output matrix, we identify the PADE actions

\footnotetext{
${ }^{12}$ For additional details of other projects, see the LBDN subprojects of investment (2012, pp. 246-253).
} 
Table 1: Priority projects of the Brazilian Armed Forces in the period 2012-2031

\begin{tabular}{llr}
\hline $\begin{array}{c}\text { Armed Forces - } \\
\text { Project Code }\end{array}$ & \multicolumn{1}{c}{ Investment Projects } & $\begin{array}{c}\text { Value (in US\$ } \\
\text { Million) at } \\
\text { 2014 Prices }\end{array}$ \\
\hline Navy - M1 & Recovery of Operational Capacity & $2,575.8$ \\
Navy - M2 & Navy Nuclear Program & $2,013.3$ \\
Navy - M3 & Construction of the Center of Naval Power & $84,014.7$ \\
Navy - M4 & System Management Blue Amazon (SisGAAz) & $5,799.4$ \\
Navy - M5 & Naval Complex 2nd Squadron / 2nd Fleet Marine Force & $4,383.0$ \\
Navy - M6 & Safety of Navigation & 303.4 \\
Navy - M7 & Personnel & $2,404.8$ \\
\hline Army - E1 & Recovery of Operational Capacity & $5,478.8$ \\
Army - E2 & Cyber Defense & 402.7 \\
Army - E3 & New Family of Armored Vehicle (Guarani) & $9,999.6$ \\
Army - E4 & Integrated Border Monitoring (SISFRON) & $5,749.3$ \\
Army - E5 & Integrated System of Land Strategic Structures Protection (PROTEGER) & $6,343.6$ \\
Army - E6 & Antiaircraft Defense System & 412.1 \\
Army - E7 & System Missiles and Rockets (ASTROS 2020) & 549.5 \\
\hline Air Force - A1 & Organizational and Operational Management Air Force Command & $2,727.7$ \\
Air Force - A2 & Recovery of Operational Capacity & $2,659.5$ \\
Air Force - A3 & Airspace Control & 449.9 \\
Air Force - A4 & Operational Capacity of the Brazilian Air Force - FAB & $26,428.6$ \\
Air Force - A5 & Scientific - Technological Training Air Force \\
Air Force - A6 & Strengthening Aerospace and Brazilian Defense Industry & $23,936.8$ \\
Air Force - A7 & Development and Construction of Aerospace Mills & $5,451.6$ \\
Air Force - A8 & Support for Military and Civilians of the Air Force Command (COMAER) & $1,548.5$ \\
Air Force - A9 & Modernizing of Systems of Training and Post-training Human Resources & 168.8 \\
\hline Total & & $\mathbf{1 9 3 , 8 0 1 . 3}$ \\
\hline Note: Implicit deflator of the gross fixed capital formation & 0.0 \\
\hline Source: Whing & \\
\hline
\end{tabular}

Source: White Book of National Defense, Ministry of Defense, 2012 
directly linked to priority investment projects of the Armed Forces. In total, the projects for the period of 2012-2014 were subdivided into 180 actions to make up the national defense policy - 2058 (hereinafter, 2058-NDP). The expenses committed and paid for these actions during this period totalled US\$ 18.1 billion at 2014 prices (Table 2$)^{13}$. Note that about $70 \%$ of the committed and paid amount for 2058-NDP was meant for investment (GFCF) on the proposals put forth by IBGE - machinery, equipment, construction, military equipment, and research and development - and the rest was linked to defrayment (expenditure on maintenance and operation).

From the description of the investment projects presented in Table 1 and the detailed information of each of the 23 investment projects listed in LBDN (2012), we find that most of the projects strictly focused on investment, while fewer specific projects focused on sub-items distributed between investments (mostly) and defrayment (smaller part).

Table 2: National Defense Policy and investments of the Ministry of Defense, 2012-2014, in US\$ million (at 2014 prices)

\begin{tabular}{lcccc}
\hline & 2012 & 2013 & 2014 & Total 2012-2014 \\
\hline $\begin{array}{l}\text { Committed and settled expenditure of 2058 - } \\
\text { National Defense Policy }\end{array}$ & 6,524 & 5,753 & 5,816 & 18,094 \\
\hline Investment of the Ministry of Defense & 4,855 & 4,055 & 3,510 & 12,419 \\
\hline Investment of 2058 - NDP (em \%) & $74.4 \%$ & $70.5 \%$ & $60.3 \%$ & $68.6 \%$ \\
\hline $\begin{array}{l}\text { Source: Ministry of Defense, Secretariat of Institutional Organization and the } \\
\text { Department of Planning, Budget and Finance }\end{array}$ & & &
\end{tabular}

Regarding the 180 actions that make up 2058-NDP, we selected 95 actions that together accounted for $94.0 \%$ of the total amount committed and paid for the 2012-2014 period. The chosen actions were most representative of the shares in value, and some specific actions related to investment projects in the defense sector. To identify the productive sectors related to these actions, we first examined the direct expenditures of the Federal Government (through the Transparency Portal) and the favoured firms in the transactions, and then identified the performance of the origin activity sector of these companies and matched the activity sector for each of them. For these procedures, we had to use a translator between the companies' legal codes and the activity sector (CNAE 2.0), which was provided by the Federal Government, and another translator between the CNAE 2.0 activity sectors and the input-output matrix sectors, provided by IBGE.

In short, from the procedures described above, we obtained the value of the Federal Government project execution by activity sector for the 2012-2014 period for each of the PADE investment projects. From this, we could develop the sectoral composition or profile of each investment project for this period.

In order to obtain the sectoral composition or average profile of the 23 investment projects for 20 years (from 2012 to 2031, programme deadline), we analysed and criticized the primary composition of the previous step. Thus, we considered the various sub-projects, the start date of their execution, and the detailed description of each sub-project listed in LBDN (2012).

\footnotetext{
${ }^{13}$ From Table 2, 9.3\% of PADE projects (that is, US\$ 18.1 billion at 2014 prices of PND in relation to the total PADE of US\$ 193.8 billion) were executed in three years, between 2012 and 2014. If this pace of operation is maintained for 20 years (from 2012 to 2031), it would take up approximately $62 \%$ of PADE's projects.
} 
Thus, we obtained the sectoral composition or average profile of the investment projects. Below, we present the economic and social impacts for each of the 23 investment projects of the Brazilian Armed Forces. We also give the sectoral composition or average profile of the investment projects of the three Armed Forces and the total PADE projects (refer to Table 6).

\section{Methodology}

\subsection{Methodology of Measuring the GDP of the Defense and Security Production Complex}

Following Guilhoto et al. (2012) and Takasago et al. (2010), we derive the methodology, as shown below, from the input-output matrix for measuring the GDP of the defense and security complex in the Brazilian economy.

The defense and security complex is divided into three clusters: (I) input and output suppliers, (II) defense and security activities, and (III) service activities related to items (I) and (II). The GDP is obtained by adding the value added to the basic prices, the net of indirect taxes, to obtain the following expression:

$$
G D P=A V_{B P}+N I T
$$

where: $G D P=$ Gross Domestic Product; $A V_{B P}=$ Added Value at basic prices and NIT $=$ Net Indirect Taxes.

Thus, to calculate the GDP of the Aggregated I (suppliers of inputs and outputs), we use the information available in the input-output tables related to the values of inputs purchased by the defense and security complex. The input values are multiplied by the respective GDP $\left(C G D P_{i}\right)$ coefficients.

To obtain the GDP coefficients, we divide the sectoral GDP by the sectoral output $\left(X_{i}\right)$; that is,

$$
G G D P_{i}=\frac{G D P_{i}}{X_{i}}
$$

For each sector $k$ of the defense and security complex, the GDP ratio is multiplied by the input of the value of sector $i$ acquired by this sector. To avoid double counting, the sectors belonging to the defense and security complex are considered in the Aggregated II, so their inputs are not considered in Aggregated I. Thus, we have the GDP of Aggregated I for sector $k$ of the defense and security complex as follows:

$$
G D P_{k}^{I}=\sum_{i=1}^{n j \neq k} z_{i j} \cdot C G D P_{i}
$$

where: $G D P_{k}^{I}=$ Gross Domestic Product Aggregated I of the $k$ defense and security sector; $n=$ number of sectors in the input-output matrix; $z_{i j}=$ total value of input of the $i$ sector for the $k$ defense and security sector, CGDP $P_{i}=$ coefficient of the i sector GDP.

For Aggregated II, the GDP of the $k$ defense and security sector is given by

$$
G D P_{k}^{I I}=G D P_{k}
$$


where: $G D P_{k}^{I I}=$ Gross Domestic Product Aggregated II of the $k$ defense and security sector.

The Aggregated III comprises the transport sector and trade and services (other than those belonging to the defense and security complex, namely, Aggregated II). The treatment for this group of sectors is to determine the participation of the end of sector $k$ of the defense and security complex in the global final demand (coefficient), and by multiplying this ratio by the total value of services excluding the defense and security sector, we have

$$
\begin{gathered}
G D P T_{k}^{I}=\sum_{k=1}^{t} G D P_{k}^{I} \\
G D P T_{k}^{I I}=\sum_{k=1}^{t} G D P_{k}^{I I} \\
G D P T_{k}^{I I I}=\sum_{k=1}^{t} G D P_{k}^{I I I} \\
A S=G D P T r a n s+G D P T+G D P S \\
G D P T_{k}^{I I I}=A S \cdot \frac{F D_{k}}{G F D}
\end{gathered}
$$

where: $A S=$ aggregated services; GDPTrans = transport sectors GDP not linked to defense and security; GDPT = trade sector GDP; GDPS = service sectors GDP not linked to defense and security; $G D P T_{k}^{I I I}=$ gross domestic product Aggregated III of the $k$ defense and security sector; $F D_{k}=$ final demand of the $k$ defense and security sector; GFD = global final demand of the economy.

The GDP of the $k$ defense and security sector is given by:

$$
G D P_{k}^{\text {Total }}=G D P_{k}^{I}+G D P_{k}^{I I}+G D P_{k}^{I I I}
$$

While the GDP of the defense and security complex for each of its aggregates and as a whole is the sum of the GDP of each of the sectors belonging to this complex, we have:

$$
\begin{gathered}
G D P^{I}=\sum_{k=1}^{t} G D P_{k}^{I} \\
G D P^{I I}=\sum_{k=1}^{t} G D P_{k}^{I I} \\
G D P^{I I I}=\sum_{k=1}^{t} G D P_{k}^{I I I} \\
G D P^{\text {Total }}=G D P^{I}+G D P^{I I}+G D P^{I I I}
\end{gathered}
$$




\subsection{Impact Analysis}

From the basic Leontief model, we have:

$$
X=(I-A)^{-1} Y
$$

From this, we can measure the impact of changes in final demand $(Y)$, or the impact of each of its components (household consumption, government spending, investment and exports) on total output, employment, imports, taxes, wages, and added value, among others. Thus, we have:

$$
\begin{gathered}
\Delta X=(I-A)^{-1} \Delta Y \\
\Delta V=\hat{v} \Delta X
\end{gathered}
$$

$\Delta Y$ and $\Delta X$ are vectors $(n x 1)$ showing, respectively, the sector strategy and impact on the volume of output, whereas $\Delta V$ is a vector $(n x 1)$ representing the impact on variables such as employment, taxes, wages, and value added, among others. Furthermore, $\hat{v}$ is a diagonal matrix $(n x n)$, where the diagonal elements are respectively employment coefficients, tax, pay, and value added, among others, which are obtained by dividing, for each sector, the value of these variables used in total output by the total production of the corresponding sector; that is,

$$
v_{i}=\frac{V_{i}}{X_{i}}
$$

To obtain the impact on the total production volume, each of the analysed variables is added to all the elements of the vectors $\Delta X$ and $\Delta V$, on (16) and (17), respectively.

In (16), if the Leontief inverse matrix considers the secondary round repercussions due to changes in consumer spending, the values for generating the coefficients will take into account, in addition to the direct and indirect effects, the induced effect (Richardson (1972)). This additional effect corresponds to the generation of jobs (and their salaries) due to increase in income and household consumption. For example, if the variable of interest is the job, when the demand for output of a particular sector increases, there will be a direct increase in jobs in the sector itself, with further increases in the output of inputs in other sectors that supply inputs for the increase in output, generating indirect jobs. In turn, the jobs created will lead to the dynamic increase in the income of the population, with a consequent increase in household consumption. This new increase in demand, now provided by families, will drive the creation of new jobs, which due to the generation effect, are called induced jobs.

In this sense, the equation for calculating the direct effects, both indirect and induced, has the same formula (16), but obtaining A should consider the endogenization of both household consumption as workers' incomes in additional columns and rows to use the matrix, respectively.

\section{Multipliers}

From the direct coefficients and the Leontief inverse matrix, we can estimate the generation of direct and indirect employment, imports, taxes, wages, and 
value added, among others for each dollar produced for final demand in each sector of the economy. Thus,

$$
G V_{j}=\sum_{i=1}^{n} b_{i j} v_{i}
$$

where: $G V_{j}=$ it is the total impact, direct and indirect, on the variable in question; $b_{i j}$ it is the $i$-th element of the Leontief inverse matrix, and $v_{i}$ it is the direct coefficient of the variable in question.

Therefore, $G V_{j}$ is the generator effect of the variable in question for the j-th sector.

Dividing the generators by their direct coefficient gives the multipliers, which indicate how much is generated, directly and indirectly, of employment, imports, taxes, or any other variable for each directly generated unit of these items. For example, the job multiplier indicates the number of jobs created, directly and indirectly, for each direct job created. The multiplier of the $i$-th sector would then be given by:

$$
M V_{i}=\frac{G V_{i}}{v_{i}}
$$

$M V_{i}$ would represent the multiplier of the variable in question, and the other variables are as previously defined. The output multiplier indicates how much is produced for each monetary unit spent on final consumption, defined as:

$$
M P_{j}=\sum_{i=1}^{n} b_{i j}
$$

Since $M P_{j}$ is the output multiplier of the $j$-th sector and the other variables are defined as expressed above.

When the multiplication effect is restricted only to the demand for intermediate inputs, these multipliers are called multipliers of Type 1. However, when the demand of the households is endogenized in the system, taking into account the induced effect, these multipliers receive the denomination of Type 2 multipliers.

In the present paper, besides the output generators/multipliers, we have also analyzed the ones for employment, wages, compensation of self-employment, taxes, value added, and GDP for the defense and security activities and each of the 23 investment projects.

\section{Results and Discussion}

\subsection{GDP of the Defense and Security Productive Complex}

In this section, we present the results obtained by applying the methodology discussed previously.

\section{Components of the Defense and Security Productive Complex}

In this study, we consider four components of the defense and security complex, which are illustrated in Figure 1 below. 


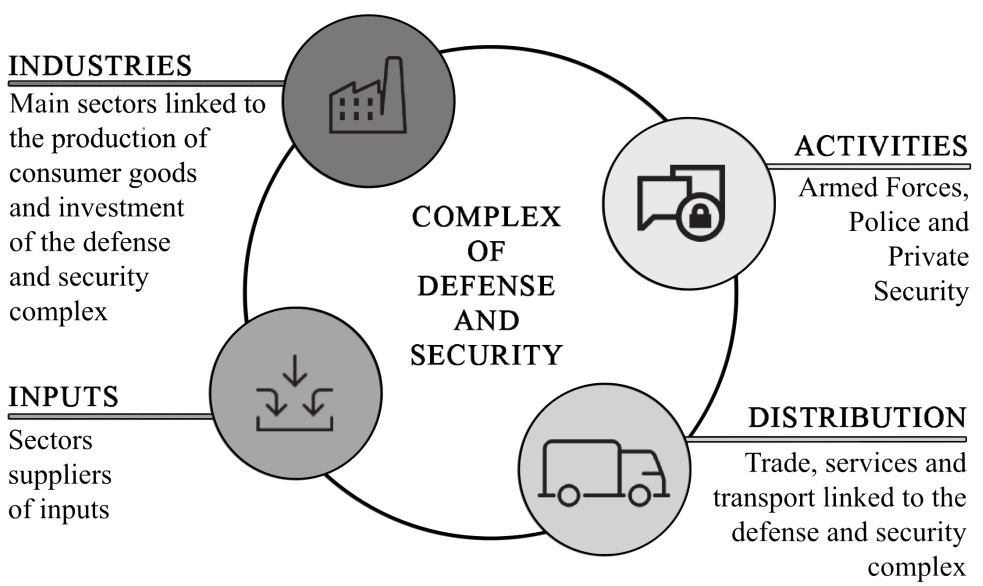

Source: Prepared by the authors.

Figure 1: Defense and security complex composition

- Defense and security activities:

Private security,

State public security,

Federal public security,

National Defense.

- Industries: leading industries related to the direct production of consumer goods and investments destined for the defense and security complex. There were six distinguished main sectors:

Weapons, ammunition and military equipment, including mechanical machinery and equipment,

Machinery and electronic equipment and information technology,

Manufacture of motor vehicles, trailers, and semi-trailers,

Other transport equipment,

Construction,

Services provided to enterprises.

- Inputs: sectors not included in the two previous components and those that provide products used as inputs for them.

- Services and distribution: trade sectors, services, and transport linked to the defense and security complex.

The methodology used in this study allows us to estimate the GDP associated with productive activities in each of the four components of the defense and security complex. The GDP of the complex then corresponds to the sum of the GDP of its components. 


\subsection{Evolution of the GDP of the Defense and Security Productive Complex, 2009-2014}

Table 3 shows the GDP of the whole defense and security complex, as well as its main components and subcomponents. From the results for 2014, the GDP of the defense and security complex was approximately US $\$ 85.8$ billion. This amount corresponded to 3.7\% of Brazil's GDP in 2014 (Table 3).

As for the results on the components and subcomponents of the defense and security complex, their respective interests did not present major changes between 2009 and 2014. The defense and security activities accounted for the largest share of the complex's GDP, approximately $54 \%$ of the total during this period; these activities are very labor-intensive, accounting for about 1.7 million direct jobs as policemen and an effective armed force, and security guards, escorts, and private patrol, paying wages $100 \%$ higher than the average Brazilian wages.

Industries on the components and inputs accounted for on average $5 \%$ and $6 \%$ of the complex's GDP, respectively, from 2009 to 2014, while service activities and distribution accounted for $35 \%$ on average over the same period. Figure 2 illustrates the shares for 2014 .

Although the aggregated industries represent a relatively small share of the complex, we emphasize that the defense and security activities demand the goods and services of high and medium-high technology sectors for weapons and ammunition (including machinery and equipment), information techno-logy and communications (including satellites), automobiles, transport equipment (including aircraft, helicopters, ships, and amphibious and bulletproof vehicles), and services from highly sophisticated companies, a fact encou-raging other factors in the domestic economy, such as technological development and employment of highly skilled labor. Moreover, the deve-lopment of technologies and military use products commonly spread to non-military products, benefiting many sectors, not just those related to the defense and security complex. Dual-use products, that is, products for military and civil purposes, mobilize technological and organizational interactions, promoting advances that extrapolate the developed product (MolasGallart (1997)).

In regards to defense and security activities only, in 2014, the results indicate that the state public security had the highest GDP, which was US\$ 19.9 billion. Private security presented a GDP of US\$ 13.1 billion. However, the subcomponent defense was responsible for the GDP of US\$ 10.7 billions. Finally, federal public security showed a smaller amount of GDP, US\$2.9 billion.

Since Brazil is a populous country (over 205 million inhabitants) with a large territory (the fifth largest country in the world, with 8.51 million $\mathrm{km}^{2}$ ), it needs to adopt vigorous defense and security measures. For law and order to work properly, policing, investigation, and protection, among other factors need to have highly effective agents distributed throughout the country. With regard to private security, its grand contribution is in line with what is happening in most of the biggest countries, with an increase in demand for vigilance services and private security in residential condos, commercial centres, corporative buildings, and semi-public sites. Thus, it is natural for security (public and private) activities to represent the largest share (three quarters) of defense and security activities, with offense activity accounting for only one 
Table 3: GDP of the defense and security complex, 2009-2014 - in US\$ million 2014

\begin{tabular}{|c|c|c|c|c|c|c|}
\hline & 2009 & 2010 & 2011 & 2012 & 2013 & 2014 \\
\hline Total & 76,049 & 82,025 & 79,185 & 82,947 & 86,345 & 85,840 \\
\hline 1. Defense and Security Activities & 40,701 & 43,109 & 42,564 & 44,249 & 46,756 & 46,729 \\
\hline 1.1. Private Security & 9,543 & 9,943 & 10,839 & 12,006 & 13,167 & 13,148 \\
\hline 1.2. State Public Security & 17,836 & 19,385 & 18,378 & 19,412 & 20,032 & 19,925 \\
\hline 1.3. Federal Public Security & 2,581 & 2,814 & 2,648 & 2,796 & 2,887 & 2,927 \\
\hline 1.4. National Defense & 10,741 & 10,967 & 10,698 & 10,035 & 10,670 & 10,729 \\
\hline 2. Industries & 3,165 & 4,191 & 3,684 & 3,989 & 3,850 & 3,449 \\
\hline 2.1. Weapons, Ammunition and Military Equipment * & 349 & 589 & 480 & 502 & 452 & 368 \\
\hline 2.2. Mach and electronic equipment and computing & 166 & 171 & 150 & 152 & 180 & 208 \\
\hline 2.3. Motor vehicles, trailers and semi-trailers & 157 & 181 & 148 & 427 & 179 & 155 \\
\hline 2.4. Other transport equipment & 355 & 519 & 345 & 517 & 497 & 446 \\
\hline 2.5. Construction & 891 & 1,101 & 1,003 & 827 & 905 & 883 \\
\hline 2.6. Services provided to enterprises & 1,247 & 1,629 & 1,560 & 1,563 & 1,637 & 1,389 \\
\hline 3. Inputs & 4,968 & 5,367 & 5,238 & 5,569 & 5,490 & 5,298 \\
\hline 4. Services and Distribution & 27,216 & 29,359 & 27,699 & 29,141 & 30,248 & 30,364 \\
\hline GDP of Brazil & $2,004,821$ & |2,156,599 & |2,241,040 & $\mid 2,280,562$ & |2,343,097 & |2,346,528 \\
\hline
\end{tabular}

Note: Implicit deflator of the GDP. Exchange rate of the Real (R\$) per Dollar (US\$) in 2014.

${ }^{*}$ Including mechanical machinery and equipment. Source: Research data. 


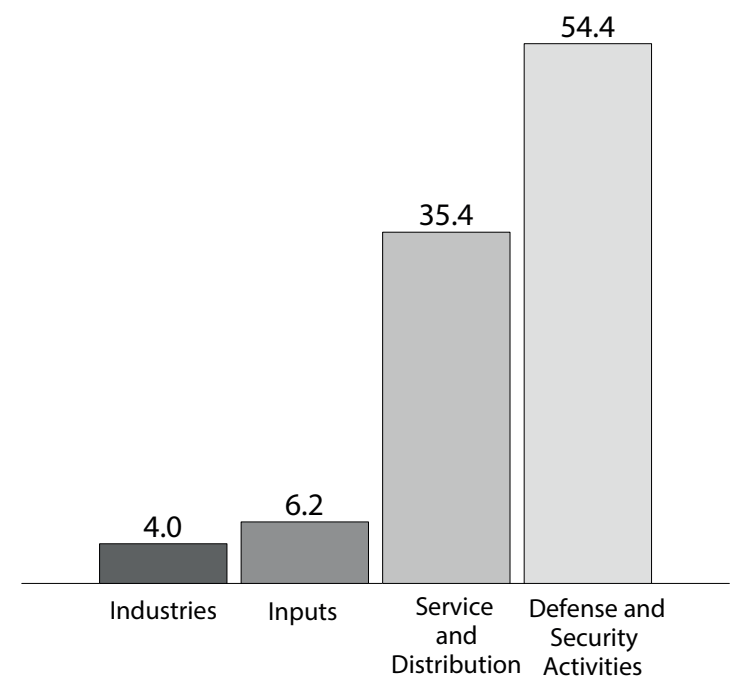

Source: research data.

Figure 2: Share of components in the GDP of the defense and security complex, 2014

quarter of all activities.

From the results, in 2014, the GDP of the defense and security complex presented a cumulative growth of $12.9 \%$ compared to 2009 . This is a modest and low growth rate relative to the GDP of Brazil, which showed an accumulated growth rate of $17 \%$ in 2014 compared to 2009 .

\subsection{Socioeconomic Impacts of Investment Projects in the Armed Forces of PADE}

Following the procedures stated previously, we traced the average sectoral profile for each of the 23 Armed Forces investment projects to measure its economic impacts via the generator effects (direct, indirect, and induced), as described earlier. Such indicators have intrinsic interest because they reveal, as the final demand changes in the sector, the impact of the economy as a whole in various economic and social dimensions.

We need to emphasize that the major transmission mechanisms of spending in the productive sector, according to the model structure presented previously, can be classified into three main groups, namely, (i) direct effects, (i) indirect effects, and (iii) induced effects. Note that the Type 1 effects include the sum of the direct and indirect effects, while the Type 2 effects also incorporate the induced effects.

Our results correspond to the realization of investments amounting to US\$ 10 million in each of the analysed projects. For comparison, they follow the impacts of increases of US\$ 10 million in vector standards of final demand of the input-output system. They also show the impact of increases by this amount in the final demand of the defense and security sectors. Projects are identified by code names as presented in Table 1 .

Table 4 presents the results of the estimated impacts considering the Type 1 effects (direct and indirect effects), while Table 5 presents them considering the Type 2 effects (direct, indirect, and induced). 
Thus, for example, for an expenditure of US\$ 10 million on investment Project A1 of the Air Force (Organizational Management and Operational Air Force Command), if we consider only the direct and indirect effects (Type 1), the impact on the value of output for the Brazilian economy as a whole would be US $\$ 18.6$ million. In terms of GDP, the increase would be of US\$ 9.7 million. Regarding the employment of persons, the results indicate the need for 410.6-equivalent man-years to meet the additional demand in the economy as a result of the project. If we consider the induced effects as well (Type 2 ), the impacts of the A1 investment project in terms of value of output and GDP would increase by respectively US\$ 33.4 and US\$ 18.6 million, requiring 829.9-equivalent man-years in the economy as a whole.

Table 4: Impacts for US\$ 10 million of 2014 in PADE's projects, final demand, and defense and security activities - Type 1

\begin{tabular}{|c|c|c|c|c|c|c|c|c|}
\hline & & \multicolumn{7}{|c|}{ Effects of Type 1} \\
\hline \multicolumn{2}{|c|}{ PROGRAM } & Output & GDP & $\begin{array}{c}\text { Employment } \\
\text { Year }\end{array}$ & $\begin{array}{l}\text { Added } \\
\text { Value }\end{array}$ & Wages & $\begin{array}{c}\text { Wages \& } \\
\text { Self- } \\
\text { employed }\end{array}$ & Taxes \\
\hline \multirow{9}{*}{ 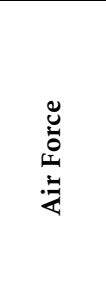 } & A1 & 18.6 & 9.7 & 410.6 & 7.9 & 3.0 & 4.0 & 2.7 \\
\hline & A2 & 18.0 & 9.6 & 297.7 & 7.6 & 3.2 & 3.9 & 2.9 \\
\hline & A3 & 17.6 & 10.1 & 323.3 & 7.8 & 2.9 & 3.6 & 3.3 \\
\hline & A4 & 18.8 & 9.6 & 245.1 & 7.2 & 3.1 & 3.6 & 3.3 \\
\hline & A5 & 17.9 & 9.7 & 243.3 & 7.6 & 3.2 & 3.8 & 3.1 \\
\hline & A6 & 19.6 & 9.6 & 220.8 & 6.9 & 2.9 & 3.2 & 3.6 \\
\hline & A7 & 18.0 & 9.9 & 273.0 & 7.8 & 3.1 & 3.7 & 3.0 \\
\hline & A8 & 17.8 & 10.0 & 445.3 & 8.3 & 3.5 & 4.5 & 2.7 \\
\hline & A9 & 18.1 & 9.7 & 467.2 & 8.0 & 3.0 & 4.1 & 2.6 \\
\hline \multirow{7}{*}{$\stackrel{\vec{E}}{2}$} & E1 & 19.3 & 9.7 & 327.4 & 7.4 & 3.0 & 3.6 & 3.3 \\
\hline & E2 & 17.7 & 10.5 & 285.8 & 7.5 & 2.7 & 3.4 & 4.0 \\
\hline & E3 & 19.3 & 9.7 & 277.6 & 7.2 & 2.9 & 3.4 & 3.4 \\
\hline & E4 & 17.1 & 9.9 & 301.8 & 7.7 & 3.1 & 3.8 & 3.2 \\
\hline & E5 & 19.3 & 9.8 & 322.8 & 7.3 & 2.9 & 3.5 & 3.4 \\
\hline & E6 & 18.5 & 9.9 & 323.6 & 7.6 & 3.0 & 3.7 & 3.3 \\
\hline & E7 & 19.2 & 9.9 & 338.6 & 7.8 & 3.1 & 3.7 & 3.1 \\
\hline \multirow{7}{*}{$\sum_{\bar{z}}^{\lambda}$} & M1 & 18.4 & 9.8 & 394.8 & 7.7 & 2.9 & 3.9 & 3.0 \\
\hline & M2 & 17.1 & 9.8 & 356.7 & 8.4 & 3.5 & 4.3 & 2.6 \\
\hline & M3 & 18.8 & 9.7 & 311.1 & 7.5 & 3.0 & 3.7 & 3.1 \\
\hline & M4 & 17.6 & 9.9 & 284.0 & 7.6 & 3.1 & 3.8 & 3.3 \\
\hline & M5 & 18.0 & 9.6 & 469.6 & 8.3 & 3.1 & 4.4 & 2.2 \\
\hline & M6 & 18.7 & 9.7 & 271.4 & 7.3 & 3.1 & 3.5 & 3.3 \\
\hline & M7 & 18.0 & 10.0 & 456.2 & 8.1 & 3.1 & 4.1 & 2.8 \\
\hline \multirow{4}{*}{ 氶 } & $\overline{\text { DF1 }}$ & 17.2 & 10.3 & 486.4 & 8.5 & 2.8 & 3.7 & 2.6 \\
\hline & DF2 & 14.0 & 9.7 & 357.5 & 9.2 & 5.7 & 5.9 & 2.2 \\
\hline & DF3 & 18.2 & 9.7 & 434.0 & 8.1 & 3.0 & 4.1 & 2.5 \\
\hline & DF4 & 18.3 & 9.7 & 374.9 & 8.0 & 2.4 & 3.4 & 2.4 \\
\hline \multirow{4}{*}{ 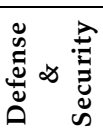 } & DS1 & 12.7 & 10.2 & 679.8 & 9.5 & 5.8 & 6.2 & 2.6 \\
\hline & DS2 & 12.7 & 9.8 & 343.5 & 9.5 & 6.3 & 6.4 & 1.6 \\
\hline & DS3 & 11.9 & 9.9 & 129.6 & 9.6 & 6.0 & 6.1 & 2.1 \\
\hline & DS 4 & 13.7 & 9.8 & 278.5 & 9.3 & 5.5 & 5.6 & 2.4 \\
\hline
\end{tabular}

Note: The description with the name of each program is described in Table 1 Source: Research data

As for the impact of Type 1 effects, we find that the investment projects first showed lower variations of up to $15 \%$ compared to output and GDP, and then showed above $75 \%$ for tax variables and jobs, demonstrating great heterogeneity in the latest indicators. However, when you add the induced effect 
(see Table 5), this heterogeneity decreases, because the income effect on consumption is taken into account, which is more in many industry and service sectors. Furthermore, no project stands out strongly with greater impact for all the variables shown in Table 4 .

Still, considering the Type 1 effects, we emphasize that the impacts of PADE's investment projects in terms of output value are on average higher than those obtained through the final demand vector standard or incremental activity sector, defense and security.

We find that the investment projects of the Armed Forces have superior impact in terms of technology and quality employment compared to the Brazilian productive structure or composition of final demand; they demand directly from the productive sectors at the forefront technology related to information technology and telecommunication, machinery and equipment, software, and military equipment. In addition, the direct impact stands out in the sectors of architectural and engineering activity, technical testing and analysis, and scientific research and development, generating innovation spillover to the Brazilian economy.

When we consider the Type 2 effects, the DS1, DS2, DS2, and DS4 defense and security activities show better performance in all Table 5 indicators. Also, note the impact in terms of wages in case of shocks in final demand of the defense and security sectors. As indicated earlier, these sectors are wageintensive compared to other sectors of the economy, making the income effect (i.e. induced employment effect) expressive. In line with the highest average compensation of the defense and security sector staff, we find that in the Type 2 effects, the impacts of increase in final demand of the defense and security sectors stand out in all the dimensions considered (GDP, added value, wages and self-employed, and employment), as shown in Table 5 .

When we consider a simple average of the impacts, we find that an increase of US\$ 10 million in the final defense and security sector demand leads to an increase of US\$23.3 million in the GDP of the economy (Table 5). This increase, following the final demand vectors of the standard input-output system, would raise the least impact of US\$19.4 million in GDP.

A detailed analysis of the productive sectors related to each investment project indicates that some sectors, especially of the medium-high and high technology industries and knowledge-intensive services are proportionally more requested to execute projets. All of these sectors in the technological vanguard are detailed in the next section.

\subsection{Sectoral Economic Impacts of Investment Projects in the Armed Forces}

Contrary to our previous finding, where numerous socioeconomic impacts are consolidated for each of the 23 PADE projects, this section exhibits sectors of the Brazilian productive structure more impacted in terms of output (Table 6) by the consolidated Air Force, Army, Navy, and PADE investment projects.

For each US $\$ 100$ million invested in PADE projects, we have the direct and indirect output of US\$185.4 million. Army projects are slightly superior, reaching US $\$ 188.2$ million. This output will be distributed in many sectors of the Brazilian economy. However, investment projects have different sectoral impacts on the armed force involved, reflecting a kind of heterogeneity of sectoral composition, as shown in Table 6. In short, we see that some sectors are 
Table 5: Impacts for US\$ 10 million of 2014 in PADE's projects, final demand and defense and security activities - Type 2

\begin{tabular}{|c|c|c|c|c|c|c|c|c|}
\hline & & & & Effect & $s$ of Typ & e 2 & & \\
\hline PROGF & $\mathbf{A M}$ & Qutnut & GDP & Employment & Added & Whase & & Tares \\
\hline & A1 & 33.4 & 18.6 & 829.9 & 15.2 & 5.3 & 7.2 & 5.0 \\
\hline & A2 & 32.6 & 18.3 & 709.8 & 14.8 & 5.6 & 7.0 & 5.2 \\
\hline & A3 & 31.7 & 18.5 & 722.4 & 14.7 & 5.2 & 6.7 & 5.5 \\
\hline$\stackrel{\mathscr{U}}{0}$ & A4 & 32.5 & 17.8 & 633.3 & 14.0 & 5.3 & 6.5 & 5.4 \\
\hline อิ & A5 & 32.3 & 18.3 & 652.2 & 14.7 & 5.6 & 6.9 & 5.3 \\
\hline$\exists$ & A6 & 32.4 & 17.3 & 584.4 & 13.2 & 5.0 & 6.0 & 5.5 \\
\hline & A7 & 32.5 & 18.5 & 683.8 & 15.0 & 5.4 & 6.8 & 5.2 \\
\hline & A8 & 33.9 & 19.6 & 903.0 & 16.3 & 6.1 & 7.9 & 5.1 \\
\hline & A9 & 33.3 & 18.8 & 896.3 & 15.5 & 5.4 & 7.4 & 4.9 \\
\hline & E1 & 33.1 & 17.9 & 717.3 & 14.1 & 5.2 & 6.6 & 5.4 \\
\hline & E2 & 31.0 & 18.4 & 660.9 & 14.0 & 4.9 & 6.2 & 6.0 \\
\hline & E3 & 32.7 & 17.7 & 656.6 & 13.8 & 5.0 & 6.3 & 5.4 \\
\hline$\widehat{\Xi}$ & E4 & 31.7 & 18.6 & 712.6 & 14.9 & 5.4 & 6.9 & 5.4 \\
\hline & E5 & 32.9 & 18.0 & 707.6 & 14.0 & 5.1 & 6.4 & 5.5 \\
\hline & E6 & 32.6 & 18.3 & 721.9 & 14.5 & 5.3 & 6.7 & 5.5 \\
\hline & E7 & 33.6 & 18.5 & 745.0 & 14.9 & 5.4 & 6.8 & 5.3 \\
\hline & M1 & 32.9 & 18.4 & 803.6 & 14.8 & 5.2 & 6.9 & 5.2 \\
\hline & M2 & 33.1 & 19.5 & 812.3 & 16.3 & 6.1 & 7.7 & 5.1 \\
\hline & M3 & 32.8 & 18.1 & 709.7 & 14.5 & 5.3 & 6.7 & 5.2 \\
\hline 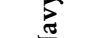 & M4 & 31.9 & 18.5 & 690.6 & 14.7 & 5.4 & 6.8 & 5.5 \\
\hline & M5 & 34.0 & 19.1 & 920.6 & 16.2 & 5.7 & 7.8 & 4.6 \\
\hline & M6 & 32.5 & 17.9 & 660.5 & 14.1 & 5.3 & 6.4 & 5.4 \\
\hline & M7 & 33.1 & 19.1 & 885.1 & 15.6 & 5.5 & 7.3 & 5.1 \\
\hline & DF1 & 31.8 & 19.0 & 899.7 & 15.7 & 5.1 & 6.8 & 4.8 \\
\hline సี & DF2 & 34.8 & 22.1 & 946.4 & 19.5 & 9.0 & 10.4 & 5.4 \\
\hline$\Xi \Xi$ & DF3 & 33.3 & 18.7 & 860.7 & 15.5 & 5.4 & 7.3 & 4.8 \\
\hline & DF4 & 32.0 & 17.8 & 761.8 & 14.8 & 4.6 & 6.3 & 4.5 \\
\hline & $\overline{\text { DS1 }}$ & 34.0 & 22.9 & 1283.0 & 20.0 & 9.2 & 10.8 & 5.9 \\
\hline$\stackrel{5}{=}$ & DS2 & 36.0 & 23.4 & 1037.4 & 20.8 & 10.0 & 11.4 & 4.8 \\
\hline$\underset{\sim}{\tilde{v}} \infty$ & DS3 & 35.9 & 23.8 & 843.1 & 21.3 & 9.8 & 11.2 & 5.4 \\
\hline & DS4 & 36.6 & 23.1 & 960.0 & 20.5 & 9.1 & 10.5 & 5.5 \\
\hline
\end{tabular}

Note: The description with the name of each program is described in Table 1. Source: Research data.

proportionally more requested, especially with regard to medium-high and high technology industries, knowledge-intensive services, and civil construction.

High and medium-high technology industries represent more than $50 \%$ of the investment projects of any of the Armed Forces, reaching 71.5\% for the Air Force. For the consolidated PADE, the medium-high and high technology industries represent $59.8 \%$ of the total composition. The main sector benefitted from the investment projects is the 'other transport equipment' sector, which includes the production of airplanes, helicopters, ships, and military combat vehicles, among others. Furthermore, there is the sector of 'heavy belic equipment, weapons and ammunition', which has special importance for Army projects.

Beyond these transformation industry sectors, a substantial portion of the investment projects' sectoral composition is from the sectors of civil construction and knowledge-intensive services; for example, information and communication, professional, technical, and scientific services. 
The civil construction sector represented $17.6 \%$ of the project composition of PADE, especially of the Navy (28.7\% of the total) and Army $(9.1 \%$ of the total) projects. Besides the construction of the naval dockyard responsible for the construction of four conventional submarines and one nuclear propulsion submarine, many investment projects foresee the construction or modernization of military bases for a variety of purposes such as supply, training centres, weapons and ammunition, hospital and health centres, science and technology laboratories, dockyards, command centres, and battalions.

Knowledge-intensive services and information represent $9.3 \%$ of the project composition of PADE, especially of the Air Force (18\% of the total) and Army (12.3\% of the total) projects. The sectors of 'system development and other information services' and 'architecture services, engineering, testing/analysis, R\&D' are the main beneficiaries. These sectors are directly linked to the technological development projects of new systems and the complex belic equipment of the Air Force and the Army; for instance, the projects of E2 - Cyber defense E4- Integrated border monitoring, A7 - Development and construction of aerospace mills, and A5 - Scientific-technological training Air Force.

Some medium-low and low technology industry sectors, for example, metallurgy, refined petroleum, metal products, and rubber and plastic products, as well as some other sectors of the economy such as financial service activities and Public Administration will also be impacted, although in less proportion. In these cases, the impacts will be mainly from indirect output, rather than direct output, because indirect output refers to the leading suppliers of the hard core defense industries and the construction sector.

Four sectors are directly responsible for around $60 \%$ of the project composition of PADE: other transport equipment; manufacture of weapons and ammunition; systems development and other information services; and architectural and engineering activities, technical testing and analysis, and R\&D. These sectors make up the core of the defense sector related to equipment acquisition and technological development. The other sectors such as 'motor vehicles, computer equipment, electronic, and optic products' (for example, the radars and satellite communication equipment for the command, control, and navigation centers and management of airspace and cyberspace) and telecommunication had smaller importance in the project composition of PADE.

In summary, we observe that investment projects of the Armed Forces have superior impacts on technological terms and job quality compared to the current Brazilian productive structure or final demand composition, for they directly demand that the productive sectors in the technological forefront related to industries and services supply heavy belic equipment, transport equipment, computer and electronic computers, telecommunications, and software and system development. Besides, we highlight the direct impacts of the engineering and R\&D services, which show innovative spillovers to the Brazilian economy in both the military and civil sectors in several studies (Mowery \& Rosenberg (1999); Mowery (2012); Guillou et al. (2009); Trebat \& Medeiros (2014)). 
Table 6: Composition of the investment projects of the Brazilian Armed Forces and impacts for each US $\$ 100$ million of 2014 (only effects of Type 1)

\begin{tabular}{|c|c|c|c|c|c|c|c|c|}
\hline \multirow{2}{*}{$\begin{array}{l}\text { Grouping and Sectors of the International } \\
\text { Standard Industrial Classification (ISIC4) }\end{array}$} & \multicolumn{2}{|c|}{ Air Force } & \multicolumn{2}{|c|}{ Army } & \multicolumn{2}{|c|}{ Navy } & \multicolumn{2}{|c|}{ PADE } \\
\hline & Share & Type 1 & Share & Type 1 & Share & Type 1 & Share & Type 1 \\
\hline Medium-high and high technology industries & 71.5 & 95.5 & 62.3 & 81.5 & 51.8 & 71.5 & 59.8 & 80.8 \\
\hline $\begin{array}{l}30 \text { - Manufacture of other transport equipament (aircrafts and) } \\
\text { helicopters; ships; military fighting vehicles; satellites) }\end{array}$ & 65.7 & 79.6 & 22.7 & 27.6 & 42.1 & 51.0 & 46.9 & 56.9 \\
\hline 252 - Manufacture of weapons and ammunition & 2.2 & 3.6 & 10.9 & 12.1 & 3.5 & 4.9 & 4.1 & 5.5 \\
\hline 29 - Manufacture of motor vehicles, trailers and semi-trailers & 0.2 & 1.3 & 10.2 & 13.1 & 2.1 & 3.5 & 2.7 & 4.2 \\
\hline 26 - Manufacture of computer, electronic and optical products & 0.6 & 1.2 & 9.0 & 11.1 & 1.9 & 2.5 & 2.5 & 3.4 \\
\hline 33 - Repair and installation of machinery and equipment & 2.6 & 4.0 & 3.3 & 4.7 & 1.0 & 2.4 & 1.9 & 3.3 \\
\hline 28 - Manufacture of machinery and equipment n.e.c. & 0.1 & 1.9 & 4.0 & 5.9 & 0.8 & 2.4 & 1.1 & 2.8 \\
\hline Others & 0.2 & 3.9 & 2.3 & 7.0 & 0.5 & 4.8 & 0.6 & 4.8 \\
\hline Construction & 3.9 & 5.6 & 9.1 & 10.8 & 28.7 & 32.6 & 17.6 & 20.5 \\
\hline $\begin{array}{l}\text { Services of information and communication and } \\
\text { professional, scientific and technical activities }\end{array}$ & 18.0 & 27.0 & 12.3 & 21.2 & 3.1 & 10.9 & 9.3 & 17.7 \\
\hline $\begin{array}{l}62 \text { - Computer programming, consultancy and related } \\
\text { activities; and } \\
63 \text { - Information service activities }\end{array}$ & 7.8 & 8.9 & 8.0 & 9.0 & 1.1 & 1.9 & 4.3 & 5.2 \\
\hline $\begin{array}{l}71-\text { Architectural and engineering activities; technical testing } \\
\text { and analysis and } \\
72 \text { - Scientific research and development }\end{array}$ & 5.8 & 6.9 & 3.6 & 4.8 & 1.3 & 2.4 & 3.1 & 4.2 \\
\hline $61-$ Telecommunications & 4.0 & 6.0 & 0.6 & 2.1 & 0.7 & 2.1 & 1.7 & 3.4 \\
\hline Others & 0.3 & 5.2 & 0.2 & 5.3 & 0.0 & 4.5 & 0.1 & 4.9 \\
\hline
\end{tabular}

Source: Research data 
Table 6: Composition of the investment projects of the Brazilian armed forces and impacts for each US $\$ 100$ million of 2014 (only effects of Type 1) (continue)

\begin{tabular}{|c|c|c|c|c|c|c|c|c|}
\hline \multirow{2}{*}{$\begin{array}{l}\text { Grouping and sectors of the International } \\
\text { Standard Industrial Classification (ISIC4) }\end{array}$} & \multicolumn{2}{|c|}{ Air Force } & \multicolumn{2}{|c|}{ Army } & \multicolumn{2}{|c|}{ Navy } & \multicolumn{2}{|c|}{ PADE } \\
\hline & Share & Type 1 & Share & Type 1 & Share & Type 1 & Share & Type 1 \\
\hline Medium-low and low technology industries & 1.1 & 18.1 & 10.8 & 33.4 & 2.2 & 23.3 & 3.1 & 23.1 \\
\hline 19 - Manufacture of coke and refined petroleum products & 0.4 & 2.9 & 4.7 & 9.5 & 1.0 & 4.4 & 1.3 & 4.7 \\
\hline 23 - Manufacture of other non-metallic mineral products & 0.1 & 1.0 & 0.9 & 2.3 & 0.2 & 3.5 & 0.3 & 2.5 \\
\hline 14 - Manufacture of wearing apparel & 0.2 & 0.2 & 1.4 & 1.5 & 0.2 & 0.2 & 0.3 & 0.4 \\
\hline 24 - Manufacture of basic metals & 0.0 & 5.9 & 0.1 & 7.7 & 0.1 & 6.3 & 0.0 & 6.4 \\
\hline $\begin{array}{l}25 \text { - Manufacture of fabricated metal products; except } \\
252 \text { - Manufacture of weapons and ammunition }\end{array}$ & 0.0 & 2.9 & 0.0 & 2.5 & 0.0 & 2.9 & 0.0 & 2.8 \\
\hline 22 - Manufacture of rubber and plastics products & 0.0 & 2.2 & 0.2 & 2.6 & 0.0 & 2.4 & 0.0 & 2.3 \\
\hline Others & 0.4 & 3.0 & 3.4 & 7.3 & 0.8 & 3.6 & 1.1 & 3.9 \\
\hline Distribution trade, transport and storage & 0.1 & 16.4 & 1.4 & 18.5 & 0.9 & 16.8 & 0.7 & 16.9 \\
\hline Other sectors of the economy & 5.5 & 21.0 & 4.2 & 22.9 & 13.4 & 30.6 & 9.4 & 26.3 \\
\hline $\begin{array}{l}64 \text { - Financial service activities, except insurance and } \\
\text { pension funding }\end{array}$ & 0.3 & 4.4 & 0.8 & 4.8 & 5.3 & 10.0 & 3.0 & 7.4 \\
\hline $\begin{array}{l}84 \text { - Public administration and defense; compulsory social } \\
\text { security }\end{array}$ & 2.1 & 2.5 & 0.6 & 1.0 & 3.1 & 3.5 & 2.4 & 2.8 \\
\hline 85 - Education & 2.6 & 2.8 & 0.4 & 0.6 & 1.3 & 1.5 & 1.6 & 1.8 \\
\hline 77 to 82 - Administrative and support service activities & 0.1 & 3.2 & 0.9 & 3.7 & 0.8 & 3.5 & 0.6 & 3.5 \\
\hline Others & 0.5 & 8.2 & 1.5 & 12.8 & 2.9 & 12.2 & 1.9 & 10.9 \\
\hline Total (all sectors) & 100.0 & 183.7 & 100.0 & 188.2 & 100.0 & 185.7 & 100.0 & 185.4 \\
\hline
\end{tabular}




\section{Final Remarks}

Brazil is one of the five most populated and largest countries in the world. In addition, it has many natural resources (like the tropical forest) and commercial resources (for example, offshore oil of the pre-salt) that need to be protected. Therefore, besides the strategic role of searching for technological autonomy, defense and security activities are vital to the maintenance of national sovereignty, safety of the population, and reduction of public insecurity, enhancing the longevity of its people.

This study measured the value chain of the defense and security complex in Brazil. The defense and security sector was delimited on the purchases made by the Brazilian government (at the federal, state, and municipal levels). This procedure is a distinction of this study because it isolates the goods with the purpose of defense and security from the goods for civil use. This is important because many products, for example, radars, planes, ships, vehicles, and communication equipment have dual use, making it practically difficult to identify the goods and services used for defense and security in the industrial classification based on economic activity. Thus, the complex was measured in an unprecedented manner for Brazil.

We used the input-output methodology that allowed the measuring of GDP from the productive activities of the defense and security complex, both upstream and downstream of the value chain.

This study has made advancements in some important directions in terms of data processing. First, we used an updated input-output system based on the New System of National Accounts (released by IBGE in 2015), which uses the latest information from the economic structure of Brazil. In addition, thanks to the extensive data gathered and our analysis, we could calculate the GDP using an input-output system in which the defense and security activities were explicit and well-defined in the productive structure of the country.

In 2014, the GDP of the defense and security complex was approximately US $\$ 85.8$ billion, corresponding to $3.7 \%$ of Brazil's GDP the same year. These numbers are significant and largely due to the downstream activities of the value chain, because these are extremely labor-intensive activities and in 2014, the defense and security activities generated about 1.7 million direct jobs, paying salaries $100 \%$ higher than the average salary of the Brazilian economy.

Even with regard to the downstream stages of the value chain, the security sector, that is, the state public security, federal public security, and private security together accounted for about $75 \%$ of the activities, with the defense sector accounting for $25 \%$. The security sector (public and private) has grown significantly in the country and currently employs 1.35 million workers.

We also found that defense and security activities can have a higher impact than the average Brazilian economy on all socioeconomic variables because the income effect of these activities (Type 2 effect) is above the average for the economy. Furthermore, defense and security activities engage highly skilled labor and provide high wages, thus inducing higher income and consumption for the various activities of the economy.

This study also estimated the direct, indirect, and induced impacts on the Brazilian economy as a whole of 23 investment projects scheduled by PADE, which forecasted a budget of US\$ 193.8 billion at 2014 prices for 2012 to 2031 in terms of output increases, employment, salary and compensation of self-employed, tax collection, value added, and GDP. Note that investment 
projects have a significant impact on the Brazilian economy because on average, every US\$1.00 invested generates an additional output of US\$3.27 and a tax collection of US\$ 0.53 in the Brazilian economy considering the direct, indirect, and induced impacts of these investments. Note also the significant potential to generate quality jobs, the consequent better pay for workers (above the economy average), and the potential to promote the consumptive induction of various other sectors of the economy. Such social and economic impacts that result from investment projects allow us to assess the investment policy of the government in the national defense sector.

Also obvious are the results that the sectors directly affected by investment projects are the medium-high and high-tech industries and knowledgeintensive services. While these are at the technological forefront, we expect them to generate technological spillover to the Brazilian industrial fabric.

Thus, beyond the fundamental importance of the military in the formation and training of human resources in their specific research institutes, their investment projects can provide important research and development advances that benefit different sectors of the economy, including the civilian sector, and the economic and social impacts might probably be more than that already measured.

Investments of the Armed Forces in technology and knowledge-intensive sectors are welcome once the current Brazilian output structure focuses on low-intensive knowledge services sectors and commodities. The demand of the Armed Forces with regard to PADE contributes to modernize the productive structure through critical technologies, with high potential to generate spillover to the civil sectors, as in the 20th century United States (Mowery (2012)) and China over the last decades (Trebat \& Medeiros (2014)). Thus, the action of the public sector in strategic areas such as technological autonomy and national sovereignty have the potential to enhance innovation, which is the main source of structural changes (Reati (2014)). Note that the investment projects of the Brazilian Armed Forces replicate, for example, the development strategy adopted in the Chinese economy in recent years (Trebat \& Medeiros (2014)), which is evaluated as successful, and this is additional reason to reinforce this type of investment in the captive and perennial space of the Brazilian industrial development agenda.

In addition to measuring the unprecedented defense and security activities in Brazil, this study contributed to the evaluation of public politics by measuring the social and economic impacts of investment projects of the Brazilian Armed Forces. We believe that this evaluation must be permanent for the route adjustments to become necessary. Additional studies should investigate whether any technological transfer occurs from the military to the civil sectors and evaluate the purchases of goods and services exclusively in the security sector. Moreover, the methodology elaborated in this paper to identify public purchases can be applied to other governmental areas for a comparative impact analysis of Brazilian public purchases.

\section{References}

Amarante, J. C. A. (2012), 'A base industrial de defesa brasileira', Texto para Discussão, Instituto de Pesquisa Econômica Aplicada (IPEA) . 
Araújo, B. C., De Negri, F. N., De Negri, J. A. \& Turchi, L. (2010), 'Determinantes da acumulação de conhecimento para inovação tecnológica nos setores industriais no Brasil: base industrial de defesa', Brasília, ABDI .

Block, F. (2008), 'Swimming against the current: the rise of a hidden developmental state in the United States', Politics E Society 36(2), 169-206.

Breakthrough-Institute (2010), Where Good Technologies Come From: Case Studies in American Innovation, Breakthrough Institute, Oakland, CA.

Correa Filho, S. L. S., Barros, D. C., Castro, B. H. R., Fonseca, P. V. R., Gornsztejn, J. et al. (2013), 'Panorama sobre a indústria de defesa e segurança no Brasil', BNDES Setorial, Rio de Janeiro (38), 373-408.

Dunne, J. P. (1995), 'The defense industrial base', Handbook of Defense Economics 1, 399-430.

Freeman, C. (2013), Economics of Industrial Innovation, Routledge.

Guilhoto, J., Azzoni, C. R. \& Ichihara, S. M. (2012), 'A participação da agricultura familiar no PIB do Nordeste, Fortaleza, Banco do Nordeste'.

Guillou, S., Lazaric, N., Longhi, C. \& Rochhia, S. (2009), 'The French defence industry in the knowledge management era: a historical overview and evidence from empirical data', Research Policy 38(1), 170-180.

URL: http://www.sciencedirect.com/science/article/pii/S0048733308002345

Hartley, K. (2008), The New Palgrave Dictionary of Economics, 2rd edn, Palgrave Macmillan, Durlauf, S.N., Blume, L.E. (eds.).

Kulve, H. \& Smith, W. A. (2003), 'Civilian-military co-operation strategies in developing new technologies', Research Policy 32(6), 955-970.

LBDN (2012), Livro Branco de Defesa Nacional, Ministério da Defesa, Brasília.

Markusen, A. R. (1986), 'Defence spending: a successful industrial policy?', International Journal of Urban and Regional Research 10(1), 105-122.

Mazzucato, M. (2015), The Entrepreneurial State: Debunking Public vs Private Sector Myths, Vol. 1, Anthem Press.

Molas-Gallart, J. (1997), 'Which way to go? Defence technology and the diversity of 'dual-use' technology transfer', Research Policy 26(3), 367-385.

Mowery, D. C. (2012), 'Defense-related R\&D as a model for "Grand Challenges” technology policies', Research Policy 41(10), 1703-1715.

Mowery, D. C. \& Rosenberg, N. (1999), Paths of Innovation: Technological Change in 20th-century America, Cambridge University Press.

OECD (2016), Main Science and Technology Indicators, Organisation for Economic Co-operation and Development. Paris, OECD.

Reati, A. (2014), 'Economic policy for structural change', Review of Political Economy 26(1), 1-22.

Richardson, H. W. (1972), 'Input-output and regional economics'. 
Rogerson, W. P. (1994), 'Economic incentives and the defense procurement process', Journal of Economic Perspectives 8(4), 65-90.

Sandler, T. \& Hartley, K. (1995), The Economics of Defense, Cambridge University Press.

Schmidt, F. H. \& Assis, L. R. S. (2013), 'A dinâmica recente do setor de defesa no Brasil: análise das características e do envolvimento das firmas contratadas'.

SIPRI (2011), Stockholm International Peace Research Institute Yearbook 2011: Armaments, Disarmament and International Security, Oxford University Press.

Smith, R. P. (1990), 'Defence procurement and industrial structure in the UK', International Journal of Industrial Organization 8(2), 185-205.

Takasago, M., Guilhoto, J., Mollo, M. \& Andrade, J. (2010), 'O potencial criador de emprego e renda do turismo no Brasil', Pesquisa e Planejamento Econômico 40(3), 431-460.

Trebat, N. M. \& Medeiros, C. A. D. (2014), 'Military modernization in Chinese technical progress and industrial innovation', Review of Political Economy 26(2), 303-324. 